\title{
Growth of Poinsettias, Nutrient Leaching, and Water-use Efficiency Respond to Irrigation Methods
}

\author{
John M. Dole and Janet C. Cole \\ Department of Horticulture and Landscape Architecture, Oklahoma State \\ University, Stillwater, OK 74078
}

Sharon L. von Broembsen

Department of Plant Pathology, Oklahoma State University, Stillwater, OK 74078

\section{Additional index words. Euphorbia pulcherrima, carbon partitioning}

\begin{abstract}
Gutbier V-14 Glory' poinsettias (Euphorbia pulcherrima Willd. Ex. Klotzsch) grown with ebb-and-flow irrigation used the least amount of water and produced the least runoff, and plants grown with capillary mats used the greatest amount of water and produced the most runoff, compared to microtube and hand-watering systems. The maximum amount of water retained by the pots and media was greatest for the microtube and ebb-and-flow systems and became progressively lower for the hand-watering and capillary mat systems. The media and leachate electrical conductivity from plants grown with subirrigation systems was higher than those grown with top irrigation. For the two top-irrigation systems (microtube and hand-watering), plants grown with $250 \mathrm{mg}$ N/liter from a $20 \mathrm{~N}-4.4 \mathrm{P}-16.6 \mathrm{~K}$ water-soluble fertilizer had greater leaf, stem, and total dry weights than those grown with $175 \mathrm{mg}$ N/liter. The two subirrigation systems (ebb-andflow and capillary mat) produced plants that were taller and had greater leaf, stem, and total dry weights when grown with 175 than with $250 \mathrm{mg}$ N/liter. The higher fertilizer concentration led to increased $\mathrm{N}, \mathrm{P}, \mathrm{Fe}$, and Mn concentration in the foliage. Nitrogen concentration was higher in top-irrigated plants than in subirrigated plants. The ebb-andflow system produced the greatest total dry weight per liter of water applied and per liter of runoff; capillary mat watering was the least efficient in regard to water applied and runoff.
\end{abstract}

Crop production in greenhouses is a highly intensive form of agriculture in which fertilizers and pesticides are used constantly to maximize production. Frequent irrigation results in contaminated runoff that could enter the ground and surface waters. Containerized plant production systems are unique because the plants are grown in a medium containing little if any mineral soil and in a container that restricts the root system. The container volume and medium components determine the amount of water and nutrients that can be retained around the root system. The limited water and nutrient reservoir of container-grown plants leads to more frequent irrigation and fertilization compared to those grown in the ground without restriction.

Irrigation strategies that conserve water likely would reduce the potential of contami-

Received for publication 6 Oct. 1993. Accepted for publication 22 Feb. 1994. Approved for publication by the Director of Oklahoma Agricultural Expt. Station (OAES). Our research was supported by Fred C. Gloeckner Foundation and by OAES under project H-2119. We thank Fritz Rheinfrank, Randall Smith, and Vicki Stamback for their data collection assistance. The cost of publishing this paper was defrayed in part by the payment of page charges. Under postal regulations, this paper therefore must be hereby marked advertisement solely to indicate this fact. nants entering surface and ground water. Recirculatory irrigation systems, such as ebband-flow, have been highly publicized as one way to reduce water use and runoff (Bauerle, 1990; Elliott, 1990; Horticultural Water Quality Alliance, 1992; Roberts, 1991). However, few published reports exist comparing irrigation systems on the basis of water use. For chrysanthemums [Dendranthema xgrandiflorum (Ramat.) Kitamura] grown in peatwool, Blom and Piott (1992) found that microtube-irrigated plants had higher fresh weight than ebb-and-flow-irrigated plants when data were collected at the pea-size bud stage, but no differences between the systems were found at anthesis. George (1989) also found no differences in the height, bract diameter, and dry weights of poinsettias grown with either hand-watering, microtube, or ebband-flow irrigation systems. However, George found that percent runoff (amount of runoff $\div$ amount of water applied) was $43 \%$ and $29 \%$ greater for hand-watering and microtubeirrigation systems, respectively, than for ebband-flow. The amount of water retained by pots and medium was similar for all systems. Holcomb et al. (1992) also noted that ebb-andflow reduced water use by $\approx 40 \%$ compared to hand-watering in the production of Hedera helix L., but it did not influence plant growth. Hannings et al. (1974) found that chrysanthemums grown with capillary mat irrigation had equal or higher total dry weight and were as tall as those grown with hand-watering.

In comparing irrigation systems, the optimum nutrient concentrations may vary with the irrigation system. Barrett (1991), Horticultural Water Quality Alliance (1992), and Nelson (1991) have stated that plants grown with ebb-and-flow irrigation should receive a lower fertilizer concentration than handwatered plants. Optimum fertilizer concentrations for constant liquid fertilization range from 75 to $400 \mathrm{mg} \mathrm{N} /$ liter for poinsettias, depending on the leaching fraction (Hartley, 1992; Ku and Hershey, 1991; Yelanich and Biernbaum, 1990).

Our objective was to compare four irrigation systems (hand-watering, capillary mat, microtube, and ebb-and-flow) and two fertilizer rates in regard to poinsettia plant growth, nutrient leaching, and water-use efficiency.

\section{Materials and Methods}

Poinsettia production, year 1 (1991). Poinsettia cuttings were propagated from stock plants on 26 July 1991 and rooted in foam blocks under intermittent mist. Before insertion, cutting bases were treated with rooting powder containing $0.1 \%$ indole-3-butyric acid (Hormex Rooting Powder no. 1; Brooker Chemical, N. Hollywood, Calif.). Rooted cuttings were planted $28 \mathrm{Aug}$. in pots $15 \mathrm{~cm}$ in diameter $(1360 \mathrm{ml})$ using a commercial peat : perlite : vermiculite medium (Fafard Growing Mix no. 2; Conrad Fafard, Springfield, Mass.). The medium had $94.1 \%$ total porosity, $77.4 \%$ total water-holding capacity, $40.9 \%$ available water, and $36.5 \%$ unavailable water, based on oven-dried medium. Plants were placed in a fiberglass-reinforced plastic greenhouse averaging 25.2/15.1C (day/night). Plants were spaced $38 \times 38 \mathrm{~cm}$ on containerized benches and grown with one of four irrigations systems 1) hand-watering (16-mm internal diameter hose and breaker nozzle), 2) microtube [2.5mm main line, 1.9-mm internal diameter leader tubes and lead weights (Chapin Watermatics, Watertown, N.Y.)], 3) capillary mat $[1.5 \times$ 1.8-m black plastic $(6 \mathrm{~mm})$ bottom layer, mat, and black, perforated plastic covering (Vorttex Capillary Watering System; OS Plastic, Norcross, Ga.)], or 4) ebb-and-flow [1.5×1.8$\mathrm{m}$ bench top, 190-liter tank, pump, and drain tube (Midwest Gromaster, St. Charles, Ill.)].

Sixteen plants were placed on each bench, and all plants in each replication were irrigated when one test plant per replication contained $<40 \%$ of the available water by weight. In the ebb-and-flow system, water was contained in a covered tank, pumped to the containerized bench top, held for $20 \mathrm{~min}$ to allow uptake by plants, and drained back to the tank for later recirculation. Water depth in the tank was measured before and after each irrigation to determine the amount of water retained by the medium and the bench top. Fertilized water was added to the tank when the water level dropped below half. Watering with the microtube and hand-watering systems ended when leachate was equal to $30 \%$ to $50 \%$ of water applied. Each of the capillary mat benches 

with water. Amount of water applied at each (Electronic Digital Meter; Great Plains Industries, Wichita, Kan.) installed in the water line. The runoff was collected from a drain under each bench. Percent runoff was determined by dividing the amount of runoff by the amount of water applied. Water-use efficiency was determined as 1 ) total plant dry weight $\div$ total water applied or 2) total plant dry weight $\div$ total runoff.

Plants were fertilized with $250 \mathrm{mg}$ N/liter from a commercial $20 \mathrm{~N}-4.4 \mathrm{P}-16.6 \mathrm{~K}$ watersoluble fertilizer intended for soilless media (Peters 20-10-20 PLS; Sierra Chemical Co. Milpitas, Calif.). Plants on the benches were leached with water monthly. For the capillary mat system, the plants were leached by handwatering once; then after draining the mats, they were leached a second time to reduce electrical conductivity (EC) in the mats. Plants were pinched to six nodes above the medium line on 16 Sept. Standard disease and insect control procedures were followed (Ecke et al., 1990). All plants received monthly drenches of $600 \mathrm{mg}$ magnesium sulfate/liter, and the amount of water used was recorded.

We ended the experiment on 29 Oct. due to circumstances outside the scope of the experiment. At that time, plant height and diameter (average of two measurements, one taken at the widest point and the second perpendicular to the first) were measured. Plants were severed into roots and shoots, dried at $40 \mathrm{C}$, and weighed. A completely randomized design was irrigated until the mats were saturated irrigation was determined with a flow meter

was used with benches as replications and plants as subsamples. Data were analyzed by the general linear model procedure with means separation by Duncan's multiple range test (SAS Institute, Cary, N.C.).

Poinsettia production, year 2(1992). Poinsettia cuttings were handled in the same manner as year 1, except the cuttings were propagated on 30 July, planted 27 Aug. 1992, decapitated 17 Sept., and grown at an average of 32.5/18.9C (day/night). Two fertilizer concentrations were used (175 or $250 \mathrm{mg} \mathrm{N} /$ liter). For the capillary mat system, one edge of the mat was draped over the edge of the bench for 20 min to allow some of the applied water to drain and reduce EC in the mat, and then the mat edge was folded up again. The water was collected in a trough that hung from the edge of the bench and was slanted slightly downward toward a bucket. All plants were leached with clear water every fifth irrigation, and water samples were collected from every third irrigation in each five irrigation cycle. Water samples were analyzed for $\mathrm{pH}$ (Fisher Accumet pH meter; Fisher Scientific, Pittsburgh), EC (Solu-Bridge; Beckman Instruments, Cedar Grove, N.J.), nitrates (cadmium reduction method, Page et al. 1982), and phosphorus (hydroquinone method, Page et al., 1982).

The design consisted of a completely randomized four $\times$ two factorial with four irrigation methods, two fertilizer levels, and benches as replications. Orthogonal contrasts were used to compare means (SAS Institute). Data collected at anthesis included plant height, diameter (average of measurements taken at the

Table 1. Effect of two top-irrigation systems (hand-watering and microtube) and two subirrigation systems (capillary mat and ebb-and-flow) on the water use and runoff of 'Gutbier V-14 Glory' poinsettias grown with $250 \mathrm{mg} \mathrm{N} /$ liter in year 1 and either 175 or $250 \mathrm{mg} \mathrm{N} /$ liter in year $2 .{ }^{\mathrm{z}}$ Means are an average of data from four (year 1) or three (year 2) replications (benches) of 16 plants each.

\begin{tabular}{|c|c|c|c|c|c|}
\hline $\begin{array}{l}\text { Irrigation } \\
\text { system }\end{array}$ & $\begin{array}{c}\text { Fertilizer } \\
\text { concn } \\
\text { (mg N/liter) }\end{array}$ & $\begin{array}{c}\text { No. } \\
\text { irrigations }\end{array}$ & $\begin{array}{l}\text { Amount } \\
\text { of water } \\
\text { applied } \\
\text { (liters) }\end{array}$ & $\begin{array}{c}\text { Amount } \\
\text { of runoff } \\
\text { (liters) }\end{array}$ & $\%$ Runoff $^{y}$ \\
\hline \multicolumn{6}{|c|}{ Year 1} \\
\hline Hand-watering & 250 & $14.3 \mathrm{a}^{\mathrm{x}}$ & $150 \mathrm{~b}$ & $48.3 \mathrm{a}$ & $32 \mathrm{a}$ \\
\hline Microtube & 250 & $15.8 \mathrm{a}$ & $124 \mathrm{~b}$ & $28.8 \mathrm{~b}$ & $23 \mathrm{~b}$ \\
\hline Capillary mat & 250 & $14.8 \mathrm{a}$ & $191 \mathrm{a}$ & $19.0 \mathrm{c}$ & $9 \mathrm{c}$ \\
\hline Ebb-and-flow & 250 & $16.3 \mathrm{a}$ & $93 \mathrm{c}$ & $11.5 \mathrm{c}$ & $12 \mathrm{c}$ \\
\hline \multicolumn{6}{|c|}{ Year 2} \\
\hline \multirow[t]{2}{*}{ Hand-watering } & 175 & 32.3 & 337 & 145 & 43 \\
\hline & 250 & 30.0 & 308 & 123 & 40 \\
\hline \multirow[t]{2}{*}{ Microtube } & 175 & 34.0 & 268 & 105 & 39 \\
\hline & 250 & 41.0 & 313 & 127 & 40 \\
\hline \multirow[t]{2}{*}{ Capillary mat } & 175 & 37.7 & 612 & 198 & 32 \\
\hline & 250 & 37.0 & 587 & 155 & 26 \\
\hline \multirow[t]{2}{*}{ Ebb-and-flow } & 175 & 29.7 & 204 & 23 & 11 \\
\hline & 250 & 32.7 & 215 & 28 & 13 \\
\hline \multicolumn{6}{|l|}{ Year 2 contrasts } \\
\hline Top vs. subirrigation (1) & & NS & $* * *$ & NS & $* * *$ \\
\hline 175 vs. $250(2)$ & & NS & NS & NS & NS \\
\hline $1 \times 2$ Interaction & & NS & NS & NS & NS \\
\hline Capillary mat vs. ebb-and-flow (3) & & $*$ & $* * *$ & $* * *$ & $* * *$ \\
\hline $2 \times 3$ Interaction & & NS & NS & NS & NS \\
\hline Hand-watering vs. microtube (4) & & $* *$ & NS & NS & NS \\
\hline $2 \times 4$ Interaction & & NS & NS & NS & NS \\
\hline
\end{tabular}

widest point and perpendicular to the first), and quality rating ( 0 to 5 scale, $0=$ poorest and 5 = best). Plants were severed into bracts, flowers, leaves, stems, and roots; dried; and weighed. Leaf tissue was combined into one sample per replication, ground to pass through a $917-\mu \mathrm{m}$ screen (20 mesh), and stored in air-tight jars until analysis. Samples were analyzed for ammonia-based $\mathrm{N}$ by the macroKjeldahl method (Horowitz, 1980), P colorimetrically (Page et al., 1982), and other elements using atomic absorption spectroscopy (model 2380; Perkin-Elmer, Norwalk, Conn.). Correlations between total plant dry weight and each nutrient were determined (SAS Institute). Medium samples were collected at anthesis by taking a core of medium from the top to the bottom of each root-ball and combining samples by replication. Medium EC (Solubridge, Beckman Instruments) was determined using a 2 deionized water : 1 media dilution.

The total number of irrigations was separated into the number of irrigations per 2 weeks, starting with 4 Sept. (date of first irrigation) and ending with 26 Nov. (date of the first replication with $>50 \%$ of plants at anthesis). Thus, a third factor with six levels (number of 2-week periods) was added to the original four $\times$ two factorial and trend analysis was applied. All other irrigation and data collection procedures were the same as in year 1 .

Medium-water relations. Sixteen 1360$\mathrm{cm}^{3}$ pots per bench were filled with 1.5 liters of a commercial peat : perlite : vermiculite medium (Fafard Growing Mix no. 2; Conrad Fafard), placed on 34 benches, and handwatered for $2 \mathrm{sec} /$ pot. When one test pot per replication contained $\leq 40 \%$ of the available water, all pots on each replication (bench) were weighed. Then each pot was irrigated by 1) hand-watering, applied for $0.5,1.0,1.5,2.0$, 2.5, 3.0, or $3.5 \mathrm{sec} /$ pot; 2) microtube, applied for $10,20,30,40,50,60,70,80,90$, or $100 \mathrm{sec} /$

Table 2. Analysis of variance for number of irrigations per 2-week period for 'Gutbier V-14 Glory' poinsettias grown with two top-irrigation systems (hand-watering and microtube) and two subirrigation systems (capillary mat and ebband-flow) and either 175 or $250 \mathrm{mg} \mathrm{N} /$ liter in year 2 (1992).

\begin{tabular}{lrc}
\hline \hline Source of variation & df & Mean squares \\
\hline Replication & 2 & $2.77^{\mathrm{Ns}}$ \\
Irrigation systems (I) & 3 & $10.80^{* * *}$ \\
Fertilizer concentrations (F) & 1 & $1.36^{\mathrm{Ns}}$ \\
I $\times \mathrm{F}$ & 3 & $3.71^{* *}$ \\
Irrigation periods (P) & & \\
$\quad$ Linear & 1 & $41.49^{* * *}$ \\
$\quad$ Quadratic & 1 & $10.72^{* * *}$ \\
$\quad$ Cubic & 1 & $1.83^{\mathrm{Ns}}$ \\
I $\times \mathrm{P}$ & & \\
$\quad$ Linear & 3 & $5.67^{* * *}$ \\
$\quad$ Quadratic & 3 & $1.16^{\mathrm{Ns}}$ \\
F $\times \mathrm{P}$ & & \\
$\quad$ Linear & 1 & $0.53^{\mathrm{Ns}}$ \\
$\quad$ Quadratic & 1 & $0.42^{\mathrm{Ns}}$ \\
I $\times \mathrm{F} \times \mathrm{P}$ & & \\
$\quad$ Linear & 3 & $0.77^{\mathrm{Ns}}$ \\
$\quad$ Quadratic & 3 & $0.41^{\mathrm{Ns}}$ \\
Error & 117 & 0.66 \\
\hline ss, *,******Nonsignificant or significant at $P \leq 0.05$, \\
0.01, or 0.001, respectively. &
\end{tabular}


bench; 3) ebb-and-flow, held on bench for 150, 300, 600, 1200, 1800, 2400, 3000, 3600, 4200 , or $4800 \mathrm{sec}$; or 3 ) capillary mat, applied for $20,30,40,50,60,70,80$, or $90 \mathrm{sec} / \mathrm{bench}$. Amount of water applied and runoff were measured as previously described, except with ebb-and-flow. The water drained from each bench was measured directly. After irrigation was completed, all pots were weighed to determine water content. Capillary mats also were weighed before and after each irrigation to determine the mats' water content. One test pot per replication was weighed daily until each replication received three irrigations. Regression models for amount of water applied, runoff, and water retained by the medium and capillary mats were fitted using Tablecurve (Jandel Scientific, Corte Madera, Calif.).

\section{Results}

Number of irrigations. The total number of irrigations was not affected in year 1; however, the capillary mat system required more irrigations than the ebb-and-flow system in year 2 (Table 1). In year 2, frequency of irrigations declined curvilinearly with time (Table 2, Fig. 1). Irrigation frequency declined most with the capillary mat system and least with the hand-watering system. Capillary mat systems required the most irrigation in the first 4 weeks of production; hand-watering systems required the least.

Amount of water applied. The capillary mat system required the greatest amount of water and ebb-and-flow the least (Table 1) in both years. Nutrient concentration did not influence water use. Microtube and handwatering systems required an intermediate amount of water and were not significantly different from each other.

Amount of runoff. In year 1 , the handwatered system produced the most and the capillary mat and ebb-and-flow systems the least runoff (Table 1). In year 2, however, capillary mats produced more runoff than the other systems due to increased leaching frequency (Table 1). Microtube and hand-watering systems produced an intermediate amount of runoff and were not significantly different from each other. In regard to the mediumwater relations experiment, hand-watering produced runoff at all application volumes, but no runoff was produced by microtube or capillary mat irrigation when $<4.0$ or 11.5 liters, respectively, was applied to the bench (Fig. 2). Also, in the medium-water relations experiment, no runoff was obtained from ebb-and-flow irrigation because all runoff was recirculated back to the holding tank. During year 2, the ebband-flow system was leached using handwatering procedures, during which handwatering response curves would apply.

Percent runoff. In both years, the percent runoff was greater from the top-irrigation systems (hand-watering and microtube) than with the subirrigation systems (capillary mat and ebb-and-flow) (Table 1). In year 1 , handwatering produced a greater percentage of runoff than the microtube system, and the two subirrigation systems were not significantly

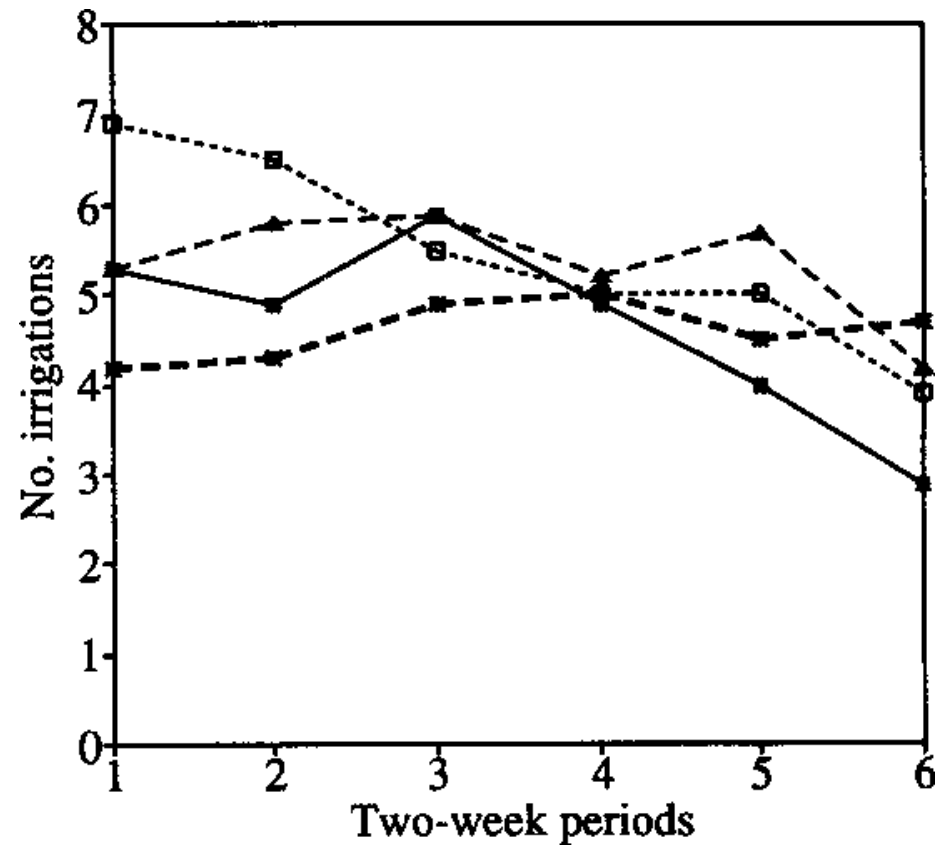

Fig. 1. Number of irrigations per 2-week period for 'Gutbier V-14 Glory' poinsettias grown with two topirrigation systems [hand-watering (*) and microtube $(\mathbf{A})$ ] and two subirrigation systems [capillary mat $(\square)$, and ebb-and-flow (ם)] in year 2 (1992).
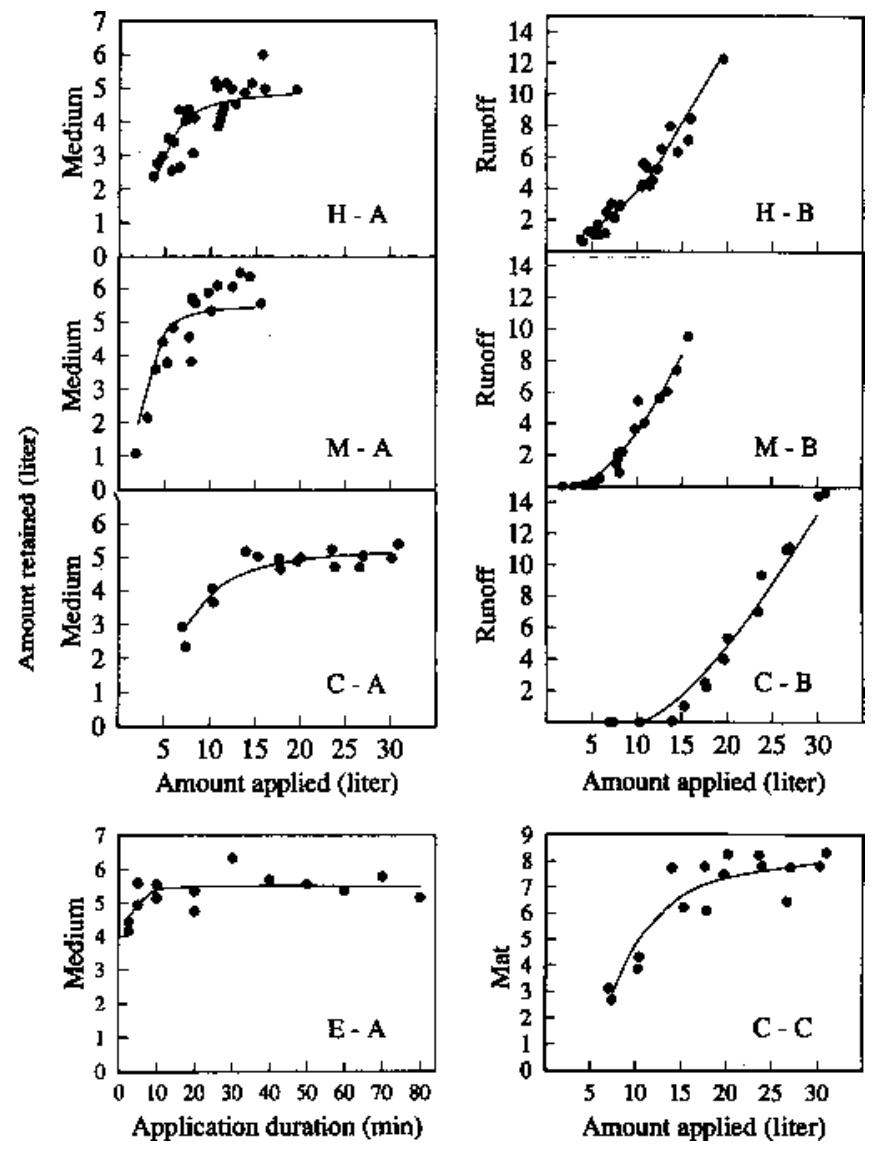

Fig. 2. The effect of increasing the water amounts applied using hand-watering $(\mathrm{H})$, microtube $(\mathrm{M})$, and capillary mat (C) systems and time of application using ebb-and-flow (E) on the amount of water retained by the pots and media (A) and runoff (B) and, for the capillary mat system, the water retained by only the mat $(C)$. The regression equation for water retained by pots and media was $y=a+b \div x^{2}[$ handwatering $\mathrm{a}=4.929$ and $\mathrm{b}=-43.126\left(r^{2}=0.63\right)$; microtube system $\mathrm{a}=5.503$ and $\mathrm{b}=-17.394\left(r^{2}=0.69\right)$; capillary mat system $\mathrm{a}=5.269$ and $\mathrm{b}=-135.045\left(r^{2}=0.87\right)$; and ebb-and-flow system $\mathrm{a}=5.496$ and $\mathrm{b}=$ $\left.-7.409\left(r^{2}=0.55\right)\right]$. The regression equation for runoff was $\mathrm{y}=\mathrm{a}+\mathrm{bx}^{2}$ [hand-watering $\mathrm{a}=0.624$ and $\mathrm{b}$ $=0.031\left(r^{2}=0.94\right) ;$ microtube system $\mathrm{a}=0.640$ and $\mathrm{b}=0.040\left(r^{2}=0.96\right) ;$ and capillary mat system $\mathrm{a}=$ -2.271 and $\left.\mathrm{b}=0.017\left(r^{2}=0.87\right)\right]$. The regression equation for water retained by capillary mats was $\mathrm{y}=$ $\mathrm{a}+\mathrm{b} \div \mathrm{x}+\mathrm{cx}^{2}$ with $\mathrm{a}=10.682, \mathrm{~b}=-57.903$, and $\mathrm{c}=-0.00096\left(r^{2}=0.84\right)$. 
different from each other. In year 2, the topirrigation systems were not significantly different from each other, and the ebb-and-flow system had the lowest percent runoff.

Medium electrical conductivity. Subirrigation resulted in higher medium EC than the top-irrigation systems, of which hand-watering produced lower EC than microtube irrigation (Table 3). Fertilizer concentration had no effect on EC.

Water analysis. Runoff water from the ebb-and-flow system had the lowest $\mathrm{pH}$, capillary mats had the second lowest $\mathrm{pH}$, and the two top-irrigation systems had the highest $\mathrm{pH}$ (Table 3). The latter two systems were not significantly different from each other. Fertilizer concentration had no effect on runoff water $\mathrm{pH}$.

The runoff water's EC was highest for the capillary mat system and decreased with ebband-flow, hand-watering, and microtube systems, respectively (Table 3 ). The EC was highest for the $250 \mathrm{mg} \mathrm{N} / \mathrm{liter}$, and interactions existed such that increasing the fertilizer concentration produced higher EC for the capillary mat system than for the ebb-and-flow system.

Nitrate concentration of runoff water was highest with capillary mats and decreased with the ebb-and-flow, hand-watering, and microtube systems, respectively (Table 3 ). Fertilizer at $250 \mathrm{mg}$ N/liter produced higher nitrate concentrations in the runoff than 175 mg N/liter, and higher fertilizer concentration produced higher nitrate concentrations in the runoff for the subirrigation systems than for the top-irrigation systems.

Phosphate concentrations were higher in the runoff from subirrigation systems than in the top-irrigation systems (Table 3). At 250 $\mathrm{mg} \mathrm{N} /$ liter, phosphate concentrations in the runoff also were higher than at $175 \mathrm{mg} \mathrm{N} / \mathrm{liter}$, and interactions existed such that increasing the fertilizer concentration increased phosphate concentration in the runoff more from the subirrigation systems than from the topirrigation systems.

Water retained by pots and medium or capillary mats. The pots and medium at container capacity retained 5.5 liters for microtube and ebb-and-flow systems for each bench, but only 5.3 and 4.9 liters were retained by pots and medium with the capillary mat and handwatering systems, respectively (Fig. 2). The capillary mats used in this experiment retained $\leq 7.9$ liters at capacity.

Height. For year 1, plants grown on the capillary mats were shortest and plants irri-

Table 3. Effect of two top-irrigation systems (hand-watering and microtube) and two subirrigation systems (capillary mat and ebb-and-flow) on the medium electrical conductivity (EC) and the $\mathrm{pH}, \mathrm{EC}$, nitrate, and phosphate concentration of runoff from the production of 'Gutbier V-14 Glory' poinsettias grown with either 175 or $250 \mathrm{mg} \mathrm{N} /$ liter. Means are an average of data from six medium samples and 12 to 20 water samples in year 2 (1992).

\begin{tabular}{|c|c|c|c|c|c|c|}
\hline \multirow[b]{2}{*}{$\begin{array}{l}\text { Irrigation } \\
\text { system }\end{array}$} & \multirow{2}{*}{$\begin{array}{c}\text { Fertilizer } \\
\text { concn } \\
\text { (mg N/liter) }\end{array}$} & \multirow{2}{*}{$\begin{array}{c}\text { Medium } \\
\text { EC } \\
\left(\mathrm{dS} \cdot \mathrm{m}^{-1}\right)\end{array}$} & \multicolumn{4}{|c|}{ Runoff } \\
\hline & & & $\mathrm{pH}$ & $\begin{array}{c}\mathrm{EC} \\
(\mathrm{mS})\end{array}$ & $\begin{array}{c}\text { Nitrates } \\
\left(\mathrm{mg} \cdot \text { liter }^{-1}\right)\end{array}$ & $\begin{array}{l}\text { Phosphates } \\
\left(\mathrm{mg} \cdot \text { liter }^{-1}\right)\end{array}$ \\
\hline \multirow[t]{2}{*}{ Hand-watering } & 175 & 0.49 & 6.62 & 1.46 & 143 & 38 \\
\hline & 250 & 0.46 & 6.52 & 1.84 & 236 & 56 \\
\hline \multirow[t]{2}{*}{ Microtube } & 175 & 0.66 & 6.50 & 1.41 & 125 & 38 \\
\hline & 250 & 0.78 & 6.38 & 1.60 & 187 & 47 \\
\hline \multirow[t]{2}{*}{ Capillary mat } & 175 & 1.12 & 6.44 & 1.84 & 236 & 50 \\
\hline & 250 & 1.22 & 6.31 & 2.40 & 381 & 76 \\
\hline \multirow[t]{2}{*}{ Ebb-and-flow } & 175 & 1.15 & 5.76 & 1.50 & 160 & 46 \\
\hline & 250 & 1.19 & 5.53 & 1.67 & 260 & 72 \\
\hline \multicolumn{7}{|l|}{ Contrasts } \\
\hline Top vs. subirrigation (1) & & $* * *$ & $* * *$ & $* * *$ & $* * *$ & $* * *$ \\
\hline 175 vs. $250(2)$ & & NS & NS & $* * *$ & $* * *$ & $* * *$ \\
\hline $1 \times 2$ Interaction & & NS & NS & NS & $*$ & $*$ \\
\hline $\begin{array}{l}\text { Capillary mat vs. } \\
\text { ebb-and-flow (3) }\end{array}$ & & NS & $* * *$ & $* * *$ & $* * *$ & NS \\
\hline $2 \times 3$ Interaction & & NS & NS & $* *$ & NS & NS \\
\hline $\begin{array}{l}\text { Hand-watering vs. } \\
\text { microtube (4) }\end{array}$ & & * & NS & $*$ & $*$ & NS \\
\hline $2 \times 4$ Interaction & & NS & NS & NS & NS & NS \\
\hline Water only ${ }^{z}$ & & --- & 7.65 & 0.44 & 6 & 1 \\
\hline
\end{tabular}

${ }^{2}$ Initial values before adding fertilizer.

ns, ${ }^{*}, * *, * * *$ Nonsignificant or significant at $P \leq 0.05,0.01$, or 0.001 , respectively.

Table 4. Effect of two top-irrigation systems (hand-watering and microtube) and two subirrigation systems (capillary mat and ebb-and-flow) on the water-use efficiency of 'Gutbier V-14 Glory' poinsettias. Means are an average of data from 30 to 32 plants in year 1 (1991).

\begin{tabular}{|c|c|c|c|c|c|}
\hline \multirow[b]{2}{*}{$\begin{array}{l}\text { Irrigation } \\
\text { system }\end{array}$} & \multicolumn{2}{|c|}{ Plant } & \multicolumn{3}{|c|}{ Dry wt } \\
\hline & $\begin{array}{l}\mathrm{Ht} \\
(\mathrm{cm})\end{array}$ & $\begin{array}{l}\operatorname{Diam}^{y} \\
(\mathrm{~cm})\end{array}$ & $\begin{array}{l}\text { Shoots } \\
\text { (g) }\end{array}$ & $\begin{array}{l}\text { Roots } \\
(\mathrm{g})\end{array}$ & $\begin{array}{l}\text { Total } \\
\text { (g) }\end{array}$ \\
\hline Hand-watering & $16.8{a b^{x}}^{x}$ & $34.8 \mathrm{~b}$ & $10.27 \mathrm{ab}$ & $2.21 \mathrm{ab}$ & $12.48 \mathrm{ab}$ \\
\hline Microtube & $17.7 \mathrm{a}$ & $39.3 \mathrm{a}$ & $12.46 \mathrm{a}$ & $2.62 \mathrm{a}$ & $15.08 \mathrm{a}$ \\
\hline Capillary mat & $15.6 \mathrm{~b}$ & $34.6 \mathrm{~b}$ & $7.68 \mathrm{~b}$ & $2.11 \mathrm{~b}$ & $9.79 \mathrm{~b}$ \\
\hline Ebb-and-flow & $16.7 \mathrm{ab}$ & $42.2 \mathrm{a}$ & $12.69 \mathrm{a}$ & $2.60 \mathrm{ab}$ & $15.29 \mathrm{a}$ \\
\hline
\end{tabular}

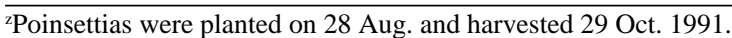

${ }^{y}$ Average of two measurements, one taken at the widest point and the second perpendicular to the first.

${ }^{x}$ Means separated within columns by Duncan's multiple range test at $P \leq 0.05$. gated with microtubes were tallest (Table 4). In year 2, poinsettias grown with top irrigation and $250 \mathrm{mg} \mathrm{N} /$ liter were taller than those grown with $175 \mathrm{mg} \mathrm{N} / \mathrm{liter}$, but plants that were subirrigated with $250 \mathrm{mg}$ N/liter were shorter than those receiving $175 \mathrm{mg} \mathrm{N} / \mathrm{liter}$ (Table 5, Fig. 3A). In addition, hand-watered plants were shorter than microtube-irrigated plants, regardless of fertilizer concentration.

Plant diameter. In year 1, plants grown with ebb-and-flow and microtube systems had a larger diameter than those grown with handwatering or capillary mat systems (Table 4). In year 2, the two subirrigation systems produced plants with larger diameters than the two topirrigation systems, which were not significantly different (Table 5, Fig. 3A). However, plants irrigated with capillary mats were smaller than plants irrigated with ebb-and-flow. Fertilizer concentration did not affect plant diameters.

Plant quality. In year 2, the subirrigated plants were of lower quality than those top irrigated (Table 5, Fig. 3B). Plants grown with ebb-and-flow irrigation were of higher quality than those grown with capillary mats, and microtube-irrigated plants were of higher quality than the hand-watered plants. Fertilizer concentration did not affect plant quality.

Days to anthesis. In year 2, plants irrigated with the two top-irrigation systems reached anthesis later than those with two subirrigation systems (Table 5, Fig. 3B). Hand-watered plants flowered sooner than microtubeirrigated plants. The plants grown with $250 \mathrm{mg}$ $\mathrm{N} /$ liter reached anthesis later than those grown with $175 \mathrm{mg} \mathrm{N} /$ liter.

Shoot dry weight. In year 1, the microtube and ebb-and-flow-irrigated plants had the highest shoot dry weight, hand-watered plants were intermediate, and capillary mat-irrigated plants had the lowest shoot dry weight (Table 4). In year 2, plants grown with the two subirrigation systems had higher bract and flower dry weights than those grown with the two top-irrigation systems, which were not significantly different from each other (Table 5, Fig. 3C). Bract and flower dry weights of ebb-and-flowirrigated plants were higher than those of the capillary mat-irrigated plants. Fertilizer did not affect bract or flower dry weight. Fertilizer at $250 \mathrm{mg} \mathrm{N} /$ liter increased leaf and stem dry weights of plants grown with the two topirrigation systems compared to $175 \mathrm{mg} \mathrm{N} /$ liter, but it decreased leaf and stem dry weights with the two subirrigation systems (Table 5, Fig. 3C). Ebb-and-flow-irrigated plants had a higher leaf dry weight than capillary matirrigated plants. The higher fertilizer concentration caused a greater decrease in stem dry weight for ebb-and-flow-irrigated plants than for capillary mat-irrigated plants.

Root dry weight. For year 1 , the root dry weight of capillary mat-irrigated plants was significantly lower than that of microtubeirrigated plants; the root dry weights of handwatered and ebb-and-flow-irrigated plants were intermediate (Table 4). However, in year 2 , the two top-irrigation systems produced plants with a lower root dry weight than the two subirrigation systems, which were not signifi- 
Table 5. Contrasts for the effects of two top-irrigation systems (hand-watering and microtube) and two subirrigation systems (capillary mat and ebb-and-flow) on the growth and water-use efficiency of 'Gutbier V-14 Glory' poinsettias plants grown with 175 or $250 \mathrm{mg}$ N/liter in year 2 (1992). ${ }^{2}$

\begin{tabular}{|c|c|c|c|c|c|c|c|c|c|c|c|c|}
\hline \multirow[b]{3}{*}{ Contrasts } & \multirow{3}{*}{$\begin{array}{l}\text { Days to } \\
\text { anthesis }\end{array}$} & \multicolumn{3}{|c|}{ Plant } & & & & & & & \multicolumn{2}{|c|}{ Water efficiency } \\
\hline & & \multirow{2}{*}{$\begin{array}{c}\mathrm{Ht} \\
(\mathrm{cm})\end{array}$} & \multirow{2}{*}{$\begin{array}{c}\operatorname{Diam}^{y} \\
(\mathrm{~cm})\end{array}$} & \multirow[b]{2}{*}{ Quality $^{v}$} & \multicolumn{6}{|c|}{ Dry wt (g) } & \multirow{2}{*}{$\begin{array}{l}\text { Runoff }^{x} \\
(\text { g•liter }\end{array}$} & \multirow{2}{*}{$\begin{array}{l}\text { Applied }^{w} \\
\left(\mathrm{~g} \cdot \text { liter }^{-1}\right)\end{array}$} \\
\hline & & & & & Bracts & Flowers & Leaves & Stems & Roots & Total & & \\
\hline Top vs. subirrigation (1) & $*$ & $*$ & $* *$ & $* *$ & $*$ & $* *$ & NS & $* *$ & $*$ & $*$ & $* * *$ & $*$ \\
\hline 175 vs. $250(2)$ & $*$ & $*$ & NS & NS & NS & NS & NS & NS & NS & NS & NS & NS \\
\hline $1 \times 2$ Interaction & NS & $*$ & NS & NS & NS & NS & $*$ & $*$ & $*$ & $*$ & NS & $*$ \\
\hline Capillary mat vs. ebb-and-flow (3) & NS & NS & $*$ & $*$ & $* *$ & $* *$ & $*$ & NS & NS & $*$ & $* * *$ & $* * *$ \\
\hline $2 \times 3$ Interaction & NS & NS & NS & NS & NS & NS & NS & $* *$ & NS & $*$ & NS & NS \\
\hline Hand-watering vs. microtube (4) & $*$ & $* *$ & NS & $*$ & NS & NS & NS & NS & $*$ & NS & NS & $* * *$ \\
\hline $2 \times 4$ Interaction & NS & NS & NS & NS & NS & NS & NS & NS & NS & NS & NS & NS \\
\hline
\end{tabular}

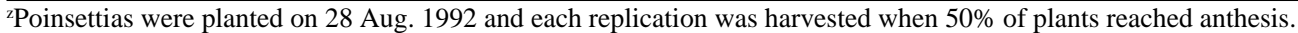

${ }^{y}$ Average of two measurements, one taken at the widest point and the second perpendicular to the first.

${ }^{x}$ Total plant dry weight $\div$ total runoff

wTotal plant dry weight $\div$ total water applied.

${ }^{v}$ On a scale from 0 to $5(0=$ poorest and $5=$ best $)$.

ns, *,**,*** Nonsignificant or significant at $P \leq 0.05,0.01$, or 0.001 , respectively.

cantly different from each other (Table 5, Fig. 3C). The microtube-irrigated plants had a higher root dry weight than the hand-watered plants, and using the higher fertilizer concentration increased the root dry weight of microtube-irrigated plants more than that of the hand-watered plants. However, using the higher fertilizer concentration decreased root dry weight of capillary mat-irrigated plants more than that of the ebb-and-flow-irrigated plants.

Total plant dry weight. In year 1, the microtube and ebb-and-flow-irrigated plants had the highest total plant dry weight, handwatered plants were intermediate, and capillary mat-irrigated plants had the lowest total plant dry weight (Table 4 ). In year 2 , microtubeirrigated plants had the highest total dry weights, and dry weights were progressively lower with the ebb-and-flow, hand-watered, and capillary mat-irrigated plants, respectively (Table 5, Fig. 3C). Fertilizer interacted with irrigation systems such that plants grown with $250 \mathrm{mg}$ N/liter had higher total dry weights for top-irrigation systems than for plants grown with $175 \mathrm{mg} \mathrm{N} / \mathrm{liter}$, but plants grown with 175 mg N/liter had higher dry weights for subirrigation systems than plants grown with $250 \mathrm{mg}$ N/liter.

Water-use efficiency. In year 2 , the ebband-flow system produced plants with the highest total plant dry weight per liter of water applied (Table 5, Fig. 3D). Microtube, handwatering, and capillary mat systems had decreasing efficiency, respectively. Fertilizer interacted with the irrigation systems such that top irrigation with $250 \mathrm{mg}$ N/liter was more efficient than with $175 \mathrm{mg}$ N/liter, but subirrigation with $175 \mathrm{mg}$ N/liter was more efficient than with $250 \mathrm{mg} \mathrm{N} /$ liter.

Ebb-and-flow was most efficient in regard to amount of total plant dry weight per liter of runoff (Table 5, Fig. 3D). Capillary mats were least efficient, and the hand-watering and microtube systems were intermediate, but not significantly different from each other. Fertilizer rate did not influence runoff efficiency.

Plant tissue nutrient concentrations. In year 2 , the higher fertilizer concentration resulted in increased foliage $\mathrm{N}, \mathrm{P}, \mathrm{Fe}$, and Mn concentrations (Table 6). The $\mathrm{N}$ concentration was also higher in plants from top-irrigation systems than from subirrigation systems. Interactions were found for $\mathrm{P}$ and $\mathrm{Fe}$, such that the increased fertilizer concentration increased $\mathrm{P}$ concentration more for plants grown with subirrigation than for those grown with top irrigation. The $\mathrm{P}$ concentration also increased more for plants grown with the capillary mat system than with the ebb-and-flow system when the fertilizer concentration was higher. The Mn concentration was higher in capillary mat-grown plants than in ebb-and-flow-grown plants. Neither irrigation system nor fertilizer rate influenced $\mathrm{K}, \mathrm{Ca}, \mathrm{Mg}$, or $\mathrm{Zn}$ concentrations in foliage.

\section{Discussion}

Hand-watering. The hand-watering system produced lower quality plants with lower dry weights than ebb-and-flow and microtube systems in year 2 (Table 5, Fig. 3C). A similar trend was noted for 1991, but no significant differences were found. The decrease in growth could be partially due to touching the plants with the hose and beaker during irrigation. Brief shaking or touching can reduce elongation and growth (Hammer et al., 1974; Turgeon and Webb, 1971). In addition, hand-watered pots retained the least amount of water of the four irrigation systems, probably due to the
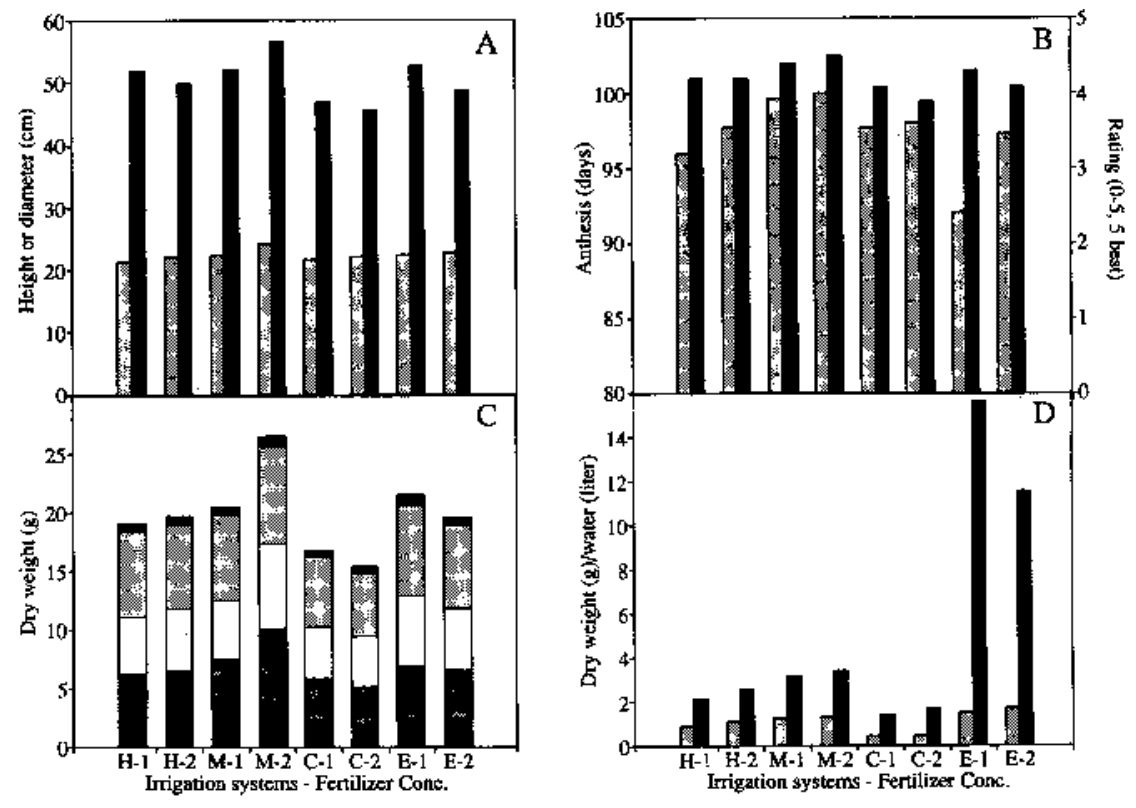

Fig. 3. Effect of two top-irrigation systems [hand-watering $(\mathrm{H})$ and microtube $(\mathrm{M})$ ] and two subirrigation systems [capillary mat (C) and ebb-and-flow (E)] on (A) height ( $\square$ ) and diameter ( $\square$ ); (B) quality ( $\square$ ) and anthesis date ( $\square$ ); (C) flower ( $\square$ ), bract ( $\square$ ), leaf ( $\square$ ), stem ( $\square$ ), and root ( $\square$ ) dry weight; and (D) applied water ( $\square$ ) and runoff ( $\square$ ) efficiency of 'Gutbier V-14 Glory' poinsettias plants grown with either 175 (1) or 250 (2) mg N/liter in year 2 (1992). Poinsettias were planted 28 Aug. and each replication was harvested when $50 \%$ of plants reached anthesis. Water-use efficiency was determined as 1$)$ total plant dry weight $\div$ total water applied or 2) total plant dry weight $\div$ total runoff. Means are an average of data from 48 plants. 
Table 6. Effect of two top-irrigation systems (hand-watering and microtube) and two subirrigation systems (capillary mat and ebb-and-flow) on the foliar nutrient concentration of 'Gutbier V-14 Glory' poinsettias plants grown with 175 or $250 \mathrm{mg}$ N/liter. ${ }^{\mathrm{z}}$ Means are an average of data from three replications of 16 plants each in year 2 (1992).

\begin{tabular}{|c|c|c|c|c|c|c|c|c|c|}
\hline \multirow{3}{*}{$\begin{array}{l}\text { Irrigation } \\
\text { system }\end{array}$} & \multirow{3}{*}{$\begin{array}{c}\text { Fertilizer } \\
\text { concn } \\
\text { (mg N/liter) }\end{array}$} & \multicolumn{8}{|c|}{ Foliar nutrient concn (dry wt) } \\
\hline & & \multicolumn{5}{|c|}{$(\%)$} & \multicolumn{3}{|c|}{$\left(\mu \mathrm{g} \bullet\right.$ liter $\left.^{-1}\right)$} \\
\hline & & $\mathrm{N}$ & $\mathrm{P}$ & $\mathrm{K}$ & $\mathrm{Ca}$ & $\mathrm{Mg}$ & $\mathrm{Zn}$ & $\mathrm{Fe}$ & $\mathrm{Mn}$ \\
\hline \multirow[t]{2}{*}{ Hand-watering } & 175 & 4.94 & 0.98 & 2.02 & 2.82 & 0.71 & 15 & 51 & $\overline{51}$ \\
\hline & 250 & 5.50 & 1.00 & 1.63 & 2.76 & 0.71 & 17 & 61 & 54 \\
\hline \multirow[t]{2}{*}{ Microtube } & 175 & 4.80 & 0.88 & 1.61 & 2.74 & 0.71 & 39 & 52 & 51 \\
\hline & 250 & 5.28 & 0.85 & 2.12 & 2.88 & 0.66 & 28 & 46 & 54 \\
\hline \multirow[t]{2}{*}{ Capillary mat } & 175 & 4.65 & 0.66 & 2.44 & 2.76 & 0.68 & 16 & 41 & 47 \\
\hline & 250 & 5.07 & 1.29 & 1.66 & 2.79 & 0.70 & 16 & 74 & 54 \\
\hline \multirow[t]{2}{*}{ Ebb-and-flow } & 175 & 4.48 & 0.84 & 1.79 & 2.76 & 0.68 & 25 & 50 & 59 \\
\hline & 250 & 5.01 & 0.95 & 1.78 & 2.71 & 0.71 & 28 & 66 & 62 \\
\hline \multicolumn{10}{|l|}{ Contrasts } \\
\hline Top vs. subirrigation (1) & & $* *$ & NS & NS & NS & NS & NS & NS & NS \\
\hline 175 vs. $250(2)$ & & $* * *$ & $* *$ & NS & NS & NS & NS & $* *$ & $*$ \\
\hline $1 \times 2$ Interaction & & NS & $* *$ & NS & NS & NS & NS & $*$ & NS \\
\hline Capillary mat vs. ebb-and-flow (3) & & NS & NS & NS & NS & NS & NS & NS & $* *$ \\
\hline $2 \times 3$ Interaction & & NS & $* *$ & NS & NS & NS & NS & NS & NS \\
\hline Hand-watering vs. microtube (4) & & NS & NS & NS & NS & NS & NS & NS & NS \\
\hline $2 \times 4$ Interaction & & NS & NS & NS & NS & NS & NS & NS & NS \\
\hline
\end{tabular}

${ }^{2}$ Poinsettias were planted on 28 Aug. 1992 and each replication harvested when $50 \%$ of plants reached anthesis.

ns, *,**,*** Nonsignificant or significant at $P \leq 0.05,0.01$, or 0.001 , respectively.

compaction from forceful top irrigation and loss of medium from flooding of the pot (Fonteno et al., 1981). Medium compaction also could result in decreased aeration and a reduction in available water (Fonteno et al., 1981).

In both years, hand-watered plants required more water than ebb-and-flow-grown plants, but no differences were found between microtube and hand-watered plants (Table 1). In year 2 , this requirement may have been partially due to the earlier anthesis of handwatered plants compared to microtubewatered plants, which would have decreased the total amount of water required and the amount of runoff (Table 5, Fig. 3B).

Microtube. The microtube system produced plants with the highest total dry weights (Table 5, Fig. 3C). In particular, microtube plants grown with $250 \mathrm{mg} \mathrm{N} /$ liter were tallest and had the highest leaf, stem, and root dry weights of any fertilizer-irrigation combination. However, the amount of water used and the runoff produced was greater for the microtube system than for the ebb-and-flow system and resulted in a lower water-use and runoff efficiency (Tables 1 and 5, Fig. 3D). Microtubeirrigated plants also required more irrigations than hand-watered plants in year 2 (Fig. 1), which may have been due to microtube plants flowering 2 to 5 days later than hand-watered plants (Table 5, Fig. 3B).

Capillary mat. The capillary mat system produced the lowest total plant dry weight and quality in both years (Table 5, Fig. $3 \mathrm{~B}$ and C). Even though leaching frequency was increased to every fifth irrigation in year 2 , the medium $\mathrm{EC}$, runoff EC, and nitrate concentration were the highest using capillary mats than using any of the other irrigation systems (year 1 data not presented, Table 3) and may have impaired plant growth. Yelanich and Biernbaum (1990) also noted that increased EC decreased poinsettia dry weight.

In addition, the capillary mat system required the most water and more irrigations in the first 4 weeks of production than the other irrigation systems. As is typical in Oklahoma, plants were subjected to high light intensity $\left(1120 \mathrm{~mol} \cdot \mathrm{m}^{-2} \cdot \mathrm{s}^{-1}\right)$ and high temperatures (34.3/ 20.7C, day/night) in September, which would have heated the large surface area of the capillary mats. Biernbaum et al. (1991) noted that $30 \%$ to $60 \%$ of total water lost from a potted plant was due to evaporation from the medium surface alone. Evaporation from the mats, accentuated by the black perforated-plastic covering, probably increased the amount of water loss, considering the area of the mats was larger than the surface area of medium in a pot. Certainly, the large amount of water that evaporated from the capillary mats was responsible for the high media and runoff EC compared to that with the other irrigation systems. Using capillary mats in greenhouses or areas of the country with lower light levels, lower temperatures, and higher humidity may allow them to be more efficient than in our Oklahoma studies (Henley, 1982).

The number of irrigations also decreased later in the growing season even though plants were larger and had a larger surface area, which shows that evaporation from the mats and pots was more important than evaporation from leaf surfaces (Table 2, Fig. 1). The importance of evaporation from mats and media is especially true considering that the mats became more shaded as the plants grew larger, reducing evaporation from the mats.

Pots and media placed on capillary mats retained less water than pots and media on ebb-and-flow benches even though both were subirrigated (Fig. 2). This difference is probably due to the longer drainage column in pots on capillary mats - columns that were created when the pots were in contact with the capillary mat. Because drainage is proportional to the length of the drainage column (Nelson, 1991), pots on a capillary mat would have drained more than the ebb-and-flow-irrigated pots.

Ebb-and-flow. In both years, the recirculatory ebb-and-flow system used the least amount of water and produced the least runoff (Table
1), which agrees with George's (1989) and Holcomb et al.'s (1992) results. Although ebband-flow did not produce the highest total plant dry weight, the water-use and water runoff efficiency was highest for ebb-and-flow (Table 5, Fig. $3 \mathrm{C}$ and D). Plants grown with ebb-and-flow irrigation may have had lower dry weights than those grown with microtubes because of the higher medium EC from ebband-flow than from microtube irrigation (Yelanich and Biernbaum, 1990). Ebb-and-flow plants fertilized with $175 \mathrm{mg} \mathrm{N} /$ liter had higher dry weights than those fertilized with $250 \mathrm{mg}$ N/liter (Table 5, Fig. 3C).

Overall, subirrigated plants grown with $175 \mathrm{mg} \mathrm{N} /$ liter had a higher total dry weight and were taller than those grown with $250 \mathrm{mg}$ $\mathrm{N} /$ liter. However, top-irrigated plants grown with $250 \mathrm{mg} \mathrm{N} /$ liter had a higher total dry weight and were taller that those grown with $175 \mathrm{mg} \mathrm{N} /$ liter (Table 5, Fig. $3 \mathrm{~A}$ and C). Barrett (1991), Horticultural Water Quality Alliance (1992), and Nelson (1991) also noted that plants grown with ebb-and-flow irrigation should receive a lower fertilizer concentration than that used for hand-watering. Our results were not due to nutritional uptake because $\mathrm{N}$, $\mathrm{P}, \mathrm{Fe}$, and $\mathrm{Mn}$ were higher in plants irrigated with $250 \mathrm{mg} \mathrm{N} /$ liter than with $175 \mathrm{mg} \mathrm{N} /$ liter, regardless of irrigation system (Table 6). No differences in $\mathrm{K}, \mathrm{Ca}, \mathrm{Mg}$, and $\mathrm{Zn}$ concentrations were found. In addition, although concentrations of $\mathrm{P}$ and $\mathrm{Ca}$ tended to be high and $\mathrm{Zn}, \mathrm{Fe}$, and Mn concentrations were low compared with normal values (Ecke et al., 1990), no correlations could be found between any nutrient and total plant dry weight (data not presented).

Microtube and hand-watering irrigation produced runoff with a lower concentration of nitrates than ebb-and-flow irrigation. However, the total quantity of runoff produced by hand-watering and microtube irrigation was greater than that produced by ebb-and-flow irrigation (Tables 1 and 3). Thus, ebb-andflow irrigation released the lowest total amount of nitrates. Capillary mats not only produced 
higher concentrations of nitrates in the runoff but also had the most runoff.

Several factors that heavily influence water efficiency were held as constant as possible in our study, but they should be investigated further. For example, more frequent leaching of subirrigation systems may be beneficial in reducing EC. However, increased leaching would probably increase the already high water use and runoff for capillary mats and would reduce the water efficiency of ebb-and-flow irrigation. Increasing the leaching fraction would probably increase runoff, but it might decrease EC, especially for subirrigated plants (Kerr and Hanan, 1985). Similarly, increasing the percentage of available water at which plants are irrigated would decrease irrigation frequency and runoff while maintaining or increasing plant growth (de Graaf-van der Zande, 1990; Kiehl et al., 1992). Nutrition and water supply are integrally related, and the relationships between the two need to be determined.

The ebb-and-flow system was the most efficient in regard to water applied and runoff compared to hand-watering, microtube, and capillary mat systems (Table 5, Fig. 3D). Ebband-flow irrigation also allowed using lower fertilizer concentrations than hand-watering or microtube systems in producing highquality poinsettia plants (Table 5, Fig. 3C). Ebb-and-flow irrigation should be considered where water supplies are limited or runoff is a problem. Microtube irrigation also produced high-quality plants but required more water and produced more runoff than the ebband-flow system (Table 1). Further research with pulse watering (frequent low-volume applications) and lower fertilizer rates may allow microtubes to be more water efficient and produce less runoff (Yelanich and Biernbaum, 1990).

\section{Literature Cited}

Barrett, J. 1991. Water and fertilizer movement in greenhouse subirrigation systems. Greenhouse Manager 10(2):89-90.

Bauerle, B. 1990. Keep an open mind about closed loop. Greenhouse Grower 8(14):53, 56, 58.

Biernbaum, J.A., W. Argo, and M. Yelanich. 1991. Effect of a pot cover on irrigation and fertilizer requirements and media nutrient stratification. HortScience 26:764. (Abstr.)

Blom, T.J. and B.D. Piott. 1992. Preplant moisture concentration and compaction of peatwool using two irrigation techniques on potted chrysanthemums. J. Amer. Soc. Hort. Sci. 117:220223.

de Graaf-van der Zande. 1990. Watering strategies in bedding plant culture: Effect on plant growth and keeping quality. Acta Hort. 272:191-196.

Ecke, P., Jr., O.A. Matkin, and D.E. Hartley. 1990. The poinsettia manual. Paul Ecke Poinsettias, Encinitas, Calif.

Elliott, G. 1990. Reduce water and fertilizer with ebb-and-flow. Greenhouse Grower 8(6):70-72, 74,75 .

Fonteno, W.C., D.K. Cassel, and R.A. Larson. 1981. Physical properties of three container media and their effect on poinsettia growth. J. Amer. Soc. Hort. Sci. 106:736-741

George, R.K. 1989. Flood subirrigation systems for greenhouse production and the potential for disease spread. MS Thesis, Michigan State Univ., East Lansing.

Hammer, P.A., C.A. Mitchell, and T.C. Weiler. 1974. Height control in greenhouse chrysanthemum by mechanical stress. HortScience 9:474475.

Hannings, D.W., P.A. Hammer, J. Kumpf, and R.W. Langhans. 1974. Further studies with the capillary mat. Florists' Rev. 154(3982):17, 55. Hartley, D.E. 1992. Poinsettias, p. 305-331. In:
R.A. Larson (ed.). Introduction to floriculture. Academic, San Diego.

Henley, R.W. 1982. Capillary mat irrigation of container-grown ornamental plants. Soc. Florists \& Nurseryman 95(6):23-25.

Holcomb, E.J., S. Gamez, D. Beattie, and G.C. Elliott. 1992. Efficiency of fertigation programs for baltic ivy and asiatic lily. HortTechnology 2:43-46.

Horowitz, W. 1980. Official methods of analysis of the Association of Analytical Chemists. 13th ed. Assn. Offic. Anal. Chem., Washington, D.C.

Horticultural Water Quality Alliance. 1992. Water quality action manual for greenhouse and nursery operators. Horticultural Water Quality Alliance, Alexandria, Va.

Kerr, G.P. and J.J. Hanan. 1985. Leaching of container media. J. Amer. Soc. Hort. Sci. 110:474480.

Kiehl, P.A., J.H. Lieth, and D.W. Burger. 1992. Growth response of chrysanthemum to various container medium moisture tension concentrations. J. Amer. Soc. Hort. Sci. 117:224-229.

Ku, C.S.M. and D.R. Hershey. 1991. Leachate electrical conductivity and growth of potted poinsettia with leaching fractions of 0 to 0.4 . J. Amer. Soc. Hort. Sci. 116:802-806.

Nelson, P.V. 1991. Greenhouse operation and management. 4thed.Prentice Hall, Englewood Cliffs, N.J.

Page, A.L., R.H. Miller, and D.R. Keeney. 1982. Methods of soil analysis. Part 2. Chemical and microbiological properties. Amer. Soc. Agron. and Soil Sci. Soc. Amer., Madison, Wis.

Roberts, D.R. 1991. Improving irrigation. Greenhouse Manager 9(10):40-45.

Turgeon, R. and J.A. Webb. 1971. Growth inhibition by mechanical stress. Science 174:961962.

Yelanich, M.V. and J.A. Biernbaum. 1990. Effect of fertilizer concentration and method of application on media nutrient concentration, nitrogen runoff and growth of Euphorbia pulcherrima 'V-14 Glory'. Acta Hort. 272:185-189. 